\title{
Glyphosate: A “Weed” in Brazilian Health
}

\author{
Eva Caroline Nunes Rezende, Jonathan Ballico de Moraes*, Fernanda Melo Carneiro, Thaís \\ Silva Guimarães, Débora de Jesus Pires and Isabela Jubé Wastowski \\ Department of Health Sciences and Biology, Universidade Estadual de Goiás, Unidade de Itumbiara, Av. Modesto de Carvalho, \\ Brasil
}

*Corresponding author: Jonathan Ballico de Moraes, Department of Health Sciences and Biology, Universidade Estadual de Goiás, Unidade de Itumbiara, Av. Modesto de Carvalho, S/№. Bairro: Distrito Agro Industrial. CEP: 75536-100, Itumbiara, Goiás, Brasil

\begin{tabular}{|c|c|}
\hline ARTICLE INFO & ABSTRACT \\
\hline Received: 慧 August 25, 2021 & $\begin{array}{l}\text { This review aims to analyze the use of Glyphosate herbicides in Brazilian agricultural } \\
\text { production: their impacts on human health and the juridic discussions about the use of }\end{array}$ \\
\hline Published: September 01, 2021 & herbicides and genetically modified organisms. It shows health issues, as metabolic and \\
\hline $\begin{array}{l}\text { Citation: Rezende, ECN.; Moraes, JB.; } \\
\text { Carneiro, FM.; Guimarães, TS; Pires, DJ; } \\
\text { Wastowski, IJ. Glyphosate: A "Weed" in }\end{array}$ & $\begin{array}{l}\text { policy is not following the constitution by do not regulate the use of pesticides. Although } \\
\text { still controversial, this subject should be discussed and encouraged in all countries, } \\
\text { especially in Brazil, which due to great pressure from the government and agribusiness, } \\
\text { there is great disincentive to carry out research related to this topic. }\end{array}$ \\
\hline
\end{tabular}

Keywords: Herbicide; Toxicity; Human; Glyphosate; Health

\section{Background}

Genetically modified organisms have already produced serial discussions over time. Its vegetable category, transgenic foods, characterizes a highly profitable and monopolizing technique, mainly in the economic aspect of agribusiness. Global production started the use of industrial agrochemicals in a cyclical way, which today represents one of the biggest revenues of transnational companies, with headquarters in developed countries [1]. In the subcategory of pesticides sold worldwide are herbicides, which are weed controlling agents, with post-emergence application and nonselective character. Among them are the herbicides that contain, in its main composition, the ingredient Glyphosate, well known by the term "Weed and Grass Killer". Its first formulation was given by the company - now German - Monsanto (Bayer), with Brazil as its biggest world consumer in the last decade, surpassing even the USA [2-4].

Monsanto was founded in 1901 as a manufacturer of artificial sweeteners. Between 1950 and 1980, it pioneered the agrochemical revolution and, in 2002, the Monsanto Company was re-established as an independent agricultural company, with the pharmaceutical units operating autonomously. Today, owned by Bayer, it maintains patents on several elements created and researched by genetic engineers worldwide, in top universities, adopting the policy of "partnership" with farmers, mainly commodity growers [4].

Created by the company in 1970, Roundup has the synthesis of glyphosate (active ingredient in the herbicide) and, in 1974, it was registered, for the first time, for use in Malaysia and the United Kingdom; two years later, in the United States. Brazil received its first sample for testing in 1972. In 1978 the product, still imported, arrived in the country to be sold and, in 1984, it started to be produced in national territory. Today, registered in more than 120 countries, it is the best-selling herbicide in the world for the control of weeds in pre-planting crops and the largest partner of Direct Tillage [4,5].

This systemic, non-selective herbicide controls weed by inhibiting the synthesis of aromatic amino acids, which are necessary for the formation of proteins in susceptible plants and, 
therefore, the load of tons used in world agriculture has been increasing. every year. In Brazil, glyphosate sales, in ton, (Figure 1) were higher in the states of Mato Grosso, Rio Grande do Sul, Paraná, Goiás and São Paulo 2. Regarding the total, in tons, of pesticides sold in Brazil in 2019, the Midwest region, followed by the South and Southeast regions, was the largest spraying of chemicals in its crops (Figure 2). The amount of glyphosate (and its salts) exceeds twice the sum of the second most used active ingredient, which is
2,4-D. Data from IBAMA 2 report more than 200 thousand tons of the active ingredient sold, in 2019, in Brazilian territory. The states with the highest consumption of glyphosate-based herbicides were Mato Grosso (38,000 tons), Rio Grande do Sul (31,000 tons) and Paraná (24,000 tons). The states of Goiás (19,000 tons) and São Paulo (19,000 tons) were not far behind, ending the list with Minas Gerais (15,000 tons) and Mato Grosso do Sul (15,000 tons).

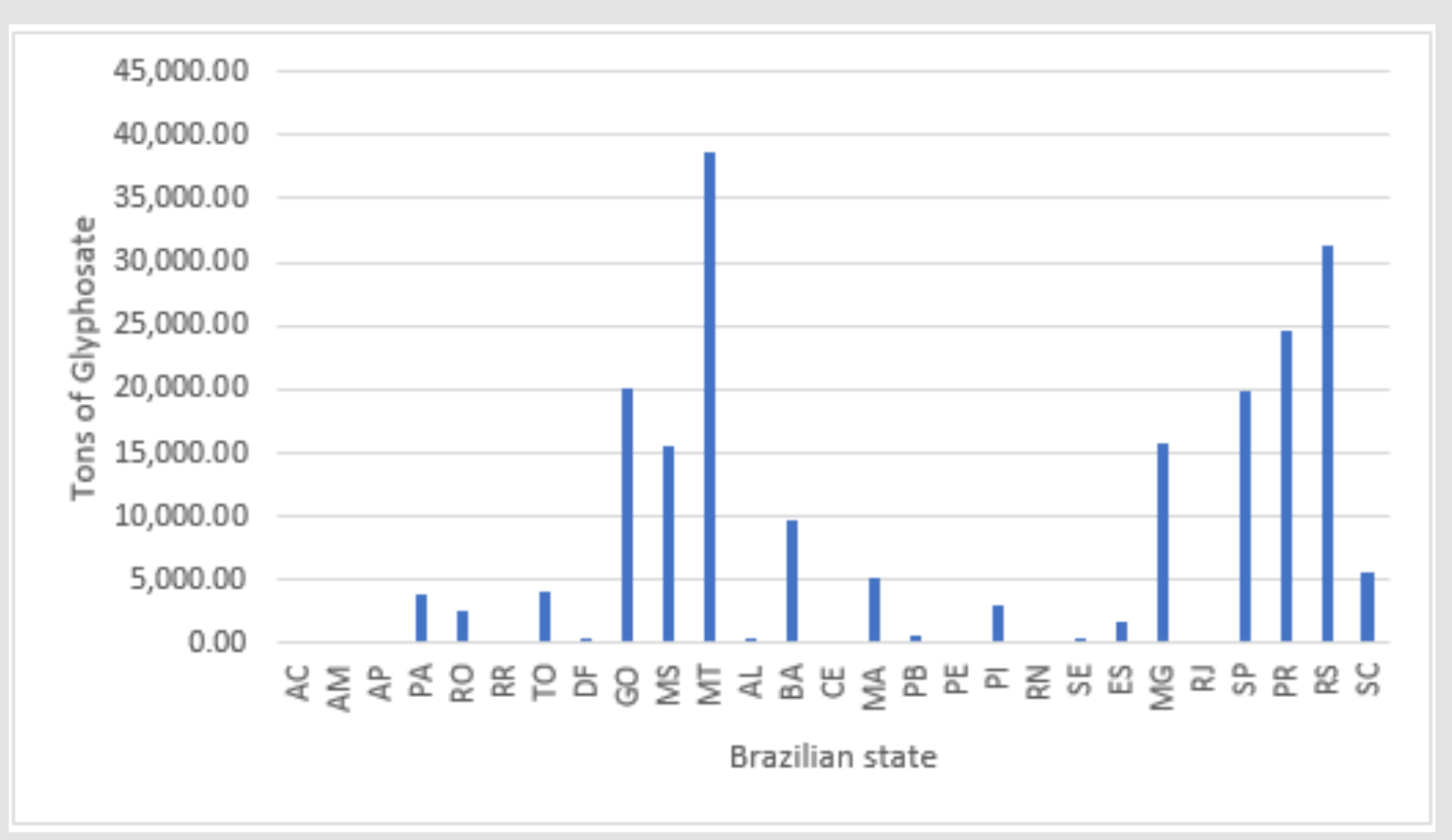

Note: Source: IBAMA ${ }^{2}$

Figure 1: Tons of Glyphosate sold in each Brazilian state in 2019.

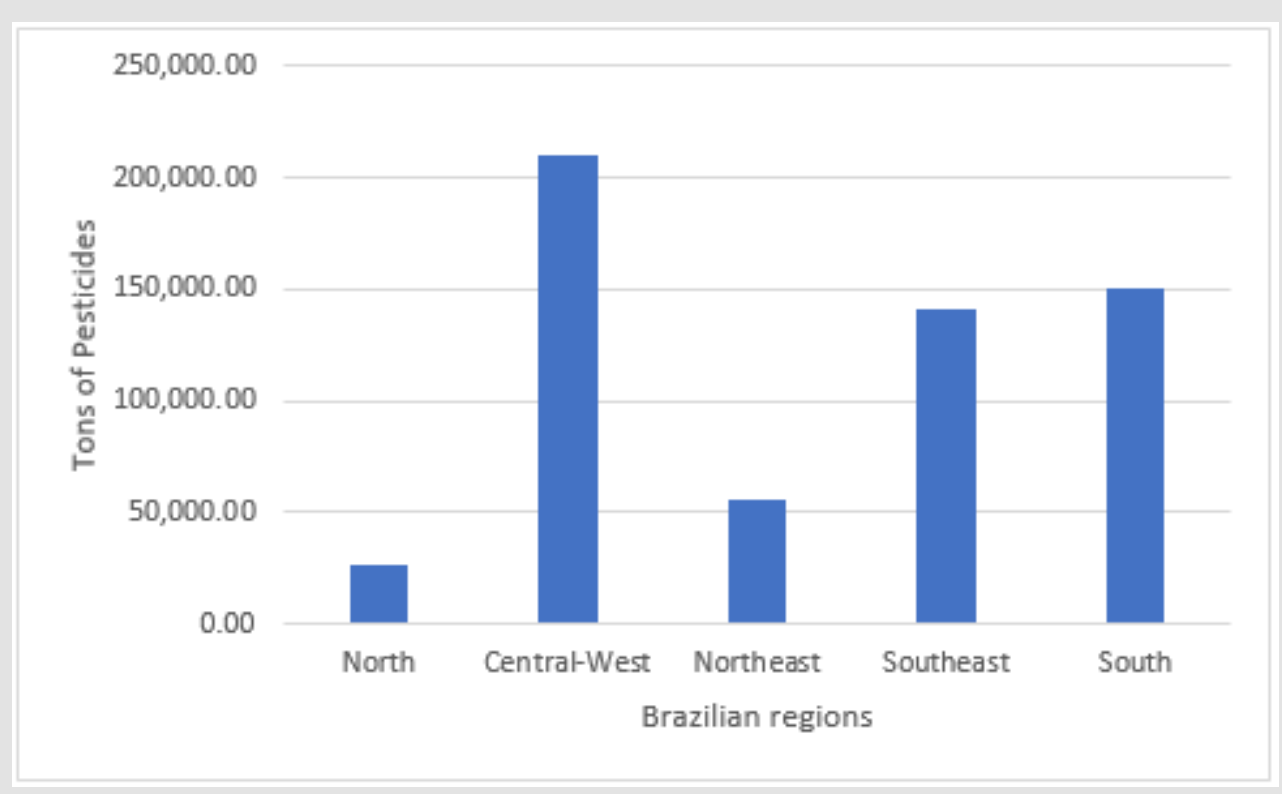

Note: Source: IBAMA²

Figure 2: Tons of pesticides sold in each Brazilian region in 2019. 
As for spraying, glyphosate is not suitable for growing crops, when these are conventional, or simple hybrids. The only products resistant to the herbicide are genetically modified seeds, that is, transgenic seeds. Because they are large-scale productions monocultures for export, often - spraying is aerial and, depending on wind speed and weather conditions, the pesticide is dispersed, reaching different locations and long distances, causing serious damage mainly to biodiversity and health human [6]. It is absorbed into soil particles, being degraded mainly through microbial metabolism. But increased soil adsorption can inhibit such metabolism, leading to slow degradation. There is also chemical photodegradation, but it does not contain significant glyphosate dissipation capacity. The balance between microbial communities present in the soil can be negatively altered with the use of the herbicide [7]. In the legal sphere, the Brazilian Federal Constitution [8] guarantees the dignity of the human person, a healthy environment that is conducive to life, with the citizen as a determining factor. In its article 225, item IV, the Magna Carta [8] is clear in saying that, in the case of a potentially degrading activity, a Prior Environmental Impact Study (EIA/RIMA) must be required, which is a duty of power public give publicity.

A balanced environment is capable of producing and satisfying the entire global population, both in terms of food, sovereign, industrial and daily. At present, we go through a series of social needs, linked to the supply of hunger and, at the same time, attention focused on human and environmental health, which requires from the sovereign and international policies of States, a contribution that involves the various segments of those interested in, and affected by, the development of the new faces of science, especially genetic engineering [9].

\section{Regulatory Issues}

The Roundup Ready technology, marketed in Brazil since the 1990s, provides transgenic seeds with high resistance to glyphosate-based herbicides, in particular Roundup, which are well known in the scientific literature for having important negative effects on aquatic and semiaquatic fauna [10]. With this, the patent market links the entire production chain in the hands of small business groups, taking away from the farmer the list of options for crop diversification.

There are three procedures that a product must go through, before entering the consumer market, which are: the environmental test (Embrapa), according to any company in the field of genetic studies; the safety study, which after evaluating the first part, ANVISA requests an adequate study, passing on the information to the decision-making bodies; finally, government approval, carried out through pre-established bodies (CONAMA, CTNBio, IBAMA) and the Ministry of the Environment [3].
Within the scope of socio-environmental impacts, there are the cyclical chains of biotic and abiotic beings, in a reckless fusion that can provide doubts and allusions to new or nonexistent concepts. The Commission for the Environment, Consumer Protection, Inspection and Control (CMA) and the Principle of Prohibition of Environmental Retrogress are part of a line drawn on the horizon, in legal matters [11].

As for consumer information, on the website of the Institute for Consumer Protection there is all the apparatus of pressure made to the government, both regarding the use of transgenic foods, and the information given to the final consumer, which by the decision-making bodies is almost negative, or even null [12].The State, as regulator and promoter of environmental and social wellbeing, must supervise the production of transgenics, demanding that environmental damage be as small as possible, as well as its immediate repair; to promote the scientific community regarding research on damage to the environment and human beings, arising from the use of this pesticide, even though the accessible results are quite imprecise $[8,13]$.

\section{Health Issues}

One of the concerns with the use of glyphosate is the fact that it is soluble in water and can be easily transported to the aquatic ecosystem, contaminating water resources. Its applications, in rural and urban areas, together with the soil leaching process, can take this chemical substance to groundwater, streams, rivers and coastal waters, causing many ecological and health problems [5]. In southern Brazil, the presence of glyphosate was detected in water sources, close to irrigated rice fields, at concentrations above $7 \mu \mathrm{g} / \mathrm{L}$ of those established by the American Environmental Protection Agency. The observation of gestational problems among rural workers exposed to Roundup was the motivation for the first studies on the toxicological potential of glyphosate for human health, especially for reproduction [14].

Marc et al. [15] demonstrated that Roundup can induce cell cycle dysfunction and inhibit the activation of the universal cell regulator CDK1/kalicin B. Abnormalities in cell cycle regulation can result in death or diseases such as cancer.Later, Richard et al. [16] observed the cytotoxic effect of glyphosate on placental cells, at doses lower than those used in agriculture. The effect increased proportionally to the concentration and exposure time and to the presence of Roundup adjuvants, i.e., the herbicide in its final formulation is more toxic than glyphosate alone, suggesting that the formulation can increase the toxicity from glyphosate. The product was able to alter the activity of the aromatase enzyme, responsible for estrogen synthesis. This study was one of the pioneers to demonstrate the endocrine disruptor effect and toxicity of glyphosate in mammalian cells. 
Benachour et al. [17] tested the toxicity of Roundup on human embryonic and placental cells. The result was the same as observed by Richard et al. [16], reinforcing Roundup's cytotoxic action and potential hormone disrupting effect, suggesting that exposure to the herbicide can affect human reproduction and fetal development, and the chemicals contained in the formulation seem to have been underestimated about the toxic impact and hormonal.

This finding was reinforced by Benachour and Seralini [18], who evaluated the toxicity of glyphosate-based herbicides and complete Roundup formulations. In this study, neonatal cells from the umbilical cord, renal embryos and placental cells were exposed to concentrations well below those recommended and found in foods and seeds. The Roundup formulation caused the death, within 24 hours, of all cells tested, by inhibiting the activity of the mitochondrial enzyme succinate dehydrogenase. In addition, necrosis induction was observed, through the release of cytosolic adenylate kinase, when in contact with the formulation, and apoptosis by enzymatic activation of caspases, when in contact with glyphosate alone, that is, the formulation containing only Glyphosate was able to induce apoptosis but not necrosis. Thus, it was shown that Roundup adjuvants are not inert, and that the combination of Glyphosate and these other components can cause cell damage and necrosis, amplifying its effect and bioaccumulation.

The ability to generate oxidative stress is another deleterious potential that has also been attributed to glyphosate. Webster and Santos [19], in an experimental study using sea trout as a model, demonstrated that exposure to the ingredient induces differentiated gene expression, with increased activity of genes associated with the expression of stress response proteins and pro-apoptotic molecules. Carcinogenesis can also be induced by glyphosate due to its role as a hormone disruptor, mainly in the development of hormone-dependent tumors, such as breast cancer. Thongprakaisang et al. [20] investigated the effect of glyphosate, in its pure formulation, on estrogen receptors (ER) and found that the chemical had a proliferative effect only in hormone-dependent breast tumors, being also able to change the expression of ER. The results of this work alert to the fact that, even at low concentrations, glyphosate has shown hormonal disrupting activity.

In addition to the effects on reproduction and cell metabolism, associated with carcinogenesis, other changes have been attributed to the use of Glyphosate and the complete Roundup formulation. Among these, heart, eye and blood problems. In this last category, changes in the immune system stand out. Regarding heart problems caused by glyphosate intoxication, arrhythmias and QT prolongation, with first-degree atrioventricular block, have been reported. In experimental animal models, changes in cardiac electrophysiology, conduction blocks and arrhythmias were also found [21].
The impacts of glyphosate on the immune response have been experimentally evaluated in animal models. Ma and Li [22] analyzed the acute toxicity to the immune system caused by the compound in carp. The cytokines interferon-gamma (IFN-gamma), interleukin-1 beta (IL-1 beta), and tumor necrosis factor-alpha (TNF-alpha) were evaluated, in addition to histopathological changes in the liver, kidneys and spleen. Marked changes in the tissues evaluated and changes in the cytokine profile were observed, suggesting dysfunction or reduced immunity.

Krüger et al. [23] exposes that the offspring of domesticated pigs, which fed on transgenic soy, contaminated by the metabolite residues of glyphosate, presented congenital malformations, especially when these creations were close to transgenic plantations. In another study, they analyzed urine, intestine, liver, muscle, spleen and kidneys from Danish dairy cows and rabbits. The genotoxic potential and oxidative stress were observed in aquatic planarians, through their exposure to different glyphosate formulations: Roundup Original, Roundup Transorb and Roundup Ready. Genotoxicity was evaluated using the comet assay and oxidative stress was evaluated by the activity of the enzyme's superoxide dismutase and catalase. These formulations were able to produce DNA damage [24].

\section{Conclusion}

Therefore, we reach the conclusions that the monopoly of the production chain, of world agriculture, has been taking place since the end of the Second World War. With the advent of chemicals in concentration camps, laboratory manipulation innovated the chemical sector by creating agrochemicals, so that large-scale production was possible, at the level of a single product per harvest. Commodities have brought deregulation in the food chain, as their fruits do not feed even half of the global population, as they are intended for the production of fuel and animal feed. The industries, in a second moment, came to introduce the new investment format, called transnational. These are sold patents for various raw materials and chemical compounds. In the end, they are responsible for selling everything from the soil fertilizer to the grain packaged in the supermarket. Monsanto - today Bayer - mentioned at the beginning of the discussion departed from the pharmacological area and recently merged with it again, transforming itself into a huge cartel; at the same time that it causes the disease, it sells the antidote, and so it monopolizes not only the market, but also the way of life and the food, social and decision-making sovereignty of peoples. The creation of Roundup, while revolutionizing agricultural techniques to combat "pests", created a vast cycle of unknown and early diseases in citizens around the world.

Glyphosate is the active ingredient of most, if not all herbicides marketed today. Combined with the other ingredients, its effects 
are highly harmful to aquatic and terrestrial environments. The studies, selected in the systematic review, clearly demonstrate the devastation of the effects arising from its use. Unfortunately, to date, no regulatory, inspection and decision-making body for this compound has given an unfavorable opinion to its trade, referring to Brazil. It is expected, however, that the censorship and barriers placed in relation to its study come to an end. Private initiatives, of personal causes, are the only ones that have achieved a satisfactory result that can counteract these transnational corporations. But, on the other hand, they invest extensively in various sectors of social policies and actions in the countries where they make real experimental laboratories, without taking into account the side effects of this intellectual, social, moral, consumerist, environmental exploitation, among all other parameters acquaintances.

\section{Acknowledgment}

The authors would like to thank the Fundação de Amparo à Pesquisa do Estado de Goiás (FAPEG).

\section{References}

1. Duke SO, Powles SB (2008) Glyphosate: a once-in-a-century herbicide. Pest Manag Sci 64(4): 319-325.

2. (2021) IBAMA - Instituto Brasileiro do Meio Ambiente e dos Recursos Naturais Renováveis. Boletins anuais de produção, importação, exportação e vendas de agrotóxicos no Brasil. Ministério do Meio Ambiente. Brasília.

3. (2019) IPEA - Instituto de Pesquisa Econômica Aplicada. Agrotóxicos no Brasil: padrões de uso, política da regulação e prevenção da captura regulatória p. 84 .

4. Bayer (2021) Products: Roundup $®$. Roundup $®$ website.

5. Rezende ECN, Carneiro FM, De Moraes JB, Wastowski IJ (2021) Trends in science on glyphosate toxicity: a scientometric study. Environ Sci Pollut Res.

6. Newman MM, Hoilett N, Lorenz N (2016) Glyphosate effects on soil rhizosphere-associated bacterial communities. Sci Total Environ 543: 155-160.

7. Adomako MO, Akyeampong S (2016) Effect of Some Commonly Used Herbicides on Soil Microbial Population. J Environ Earth Sci 6(1): 9.

8. (1988) Brasil. Constituição Da República Federativa Do Brasil. Brazil.

9. Fiorillo CAP (2020) Curso De Direito Ambiental Brasileiro. 20 ${ }^{\text {th }}$ Edn. São Paulo: Saraiva Educação.

10. Ferment G (2010) Seminário Sobre Proteção Da Agrobiodiversidade e Direito Dos Agricultores: Propostas Para Enfrentar a Contaminação
Transgênica Do Milho. (Avanci GF, Fernandes G, Avanci J, Eds.). Brasilia: MDA.

11. Rollemberg R, Prieur M, Benjamin AH, Molinaro CA, Sarlet IW, et al. (2012) Princípio Da Proibição Do Retrocesso Ambiental: Apresentação. Comissão de Meio Ambiente, Defesa Do Consumidor e Fiscalização e Controle. Brasilia.

12. Lisboa MV (2021) Chega de Transgênicos! IDEC. Instituto Brasileiro de Defesa do Consumidor.

13. (2021) Brasil. Lei da Biossegurança - Lei No 11.105, de 24 de Março de 2005. Constituição Federal.

14. Mattos MLT, Peralba MDCR, Dias SLP, Prata F, Camargo L (2002) Monitoramento Ambiental do Glifosato e do seu Metabólito (Ácido Aminometilfosfônico) na Água de Lavoura de Arroz Irrigado. Pestic Rev Ecotoxicologia e Meio Ambient.

15. Marc J, Mulner-Lorillon O, Durand G, Belle R (2003) Embryonic cell cycle for risk assessment of pesticides at the molecular level. Environ Chem Lett 1(1): 8-12.

16. Richard S, Moslemi S, Sipahutar H, Benachour N, Seralini GE (2005) Differential Effects of Glyphosate and Roundup on Human Placental Cells and Aromatase. Environ Health Perspect 113(6): 716-720.

17. Benachour N, Sipahutar H, Moslemi S, Gasnier C, Travert C, et al. (2007) Time- and Dose-Dependent Effects of Roundup on Human Embryonic and Placental Cells. Arch Environ Contam Toxicol 53(1): 126-133.

18. Benachour N, Séralini GE (2009) Glyphosate Formulations Induce Apoptosis and Necrosis in Human Umbilical, Embryonic, and Placental Cells. Chem Res Toxicol 22(1): 97-105.

19. Uren Webster TM, Santos EM (2015) Global transcriptomic profiling demonstrates induction of oxidative stress and of compensatory cellular stress responses in brown trout exposed to glyphosate and Roundup. BMC Genomics 16(1): 32

20. Thongprakaisang S, Thiantanawat A, Rangkadilok N, Suriyo T, Satayavivad J (2013) Glyphosate induces human breast cancer cells growth via estrogen receptors. Food Chem Toxicol 59: 129-136.

21. Gress S, Lemoine S, Séralini GE, Puddu PE (2015) Glyphosate-Based Herbicides Potently Affect Cardiovascular System in Mammals: Review of the Literature. Cardiovasc Toxicol 15(2): 117-126.

22. Ma J, Li X (2015) Alteration in the cytokine levels and histopathological damage in common carp induced by glyphosate. Chemosphere 128: 293-298.

23. Krüger M, Schrödl W, Pedersen I (2014) Detection of Glyphosate in Malformed Piglets. J Environ Anal Toxicol 04(05).

24. (2014) Bordin DL Avaliação da genotoxicidade e estresse oxidativo em planárias aquáticas (Dugesia schubarti) tratadas com formulações do herbicida glifosato. 
ISSN: 2574-1241

DOI: $10.26717 /$ BJSTR.2021.38.006166

Jonathan Ballico de Moraes. Biomed J Sci \& Tech Res

(C) (- This work is licensed under Creative

Submission Link: https://biomedres.us/submit-manuscript.php

$\begin{array}{ll}\text { BIOMEDICAL } & \text { Assets of Publishing with us } \\ \text { RESEARCHES } & \text { - Global archiving of articles } \\ & \text { - Immediate, unrestricted online access } \\ & \text { - Rigorous Peer Review Process } \\ & \text { - Anthors Retain Copyrights }\end{array}$

